\title{
Aksiller Lenf Nodu Diseksiyonu Sonrası Şilöz Kaçak; Nadir Fakat Belirleyici Bir Komplikasyon
}

\author{
Chilous Leak after Lymph Node Dissection; A Rare but Definitive Complication
}

\author{
Aybala Ağaç AY ${ }^{1}$, Bengi Arslan MUTLU², Abdullah CETíN ${ }^{3}$ \\ ${ }^{I}$ Kırıkkale Üniversitesi Tip Fakültesi, Genel Cerrahi A.D., KIRIKKALE \\ ${ }^{2}$ Kirlkkale Üniversitesi Tip Fakültesi, Kulak Burun Boğaz A.D., KIRIKKALE \\ ${ }^{3}$ Ankara Onkoloji Ĕgitim ve Araştırma Hastanesi, Genel Cerrahi Kliniği, ANKARA
}

\begin{abstract}
ÖZET
Lenf nodu diseksiyonu sonrası şilöz kaçak olması ise son derece nadir görülmekle birlikte, gözden kaçırıldığında ölümcül seyredebilecek bir komplikasyon olarak karşımızda durmaktadır. 2006-2010 tarihleri arasında meme kanseri sebebiyle modifiye radikal mastektomi yapılan 1294 olgunun şilöz kaçak gelişen 3'ü tartışıldı. Nadir de olsa, oluştuğunda ciddi sonuçlara yol açabilecek bir patolojinin, özellikle kanser cerrahisi sebebiyle geniş lenf nodu diseksiyonu yapılan branşlar için önemli bir komplikasyon olduğunu düşünmekteyiz.
\end{abstract}

Anahtar kelimeler: Aksiller lenf nodu diseksiyonu, şilöz kaçak, duktus torasikus

\section{GİRIŞ}

Günümüzde anser cerrahisi alanındaki gelişmelerle ve yeni tekniklerin yaygınlaşmasıyla komplikasyon oranları düşmekte olsa da bazı nadir fakat ciddi komplikasyonlar konusunda dikkatli olmak hayati bir zorunluluktur. Lenf nodu diseksiyonu sonrası şilöz kaçak olması ise son derece nadir görülmekle birlikte, gözden kaçırıldığında ölümcül seyredebilecek bir komplikasyon olarak karşımızda durmaktadır (1).

\begin{abstract}
Chile leak after lymh node dissection is rare but albeit significant issue. We discussed 3 cases with chilous leak after modified radical mastectomy(MRM) for breast cancer of 1294 MRM cases between 2006-2010. We think that it is a common problem and a major complication in disciplines which perform lymph node dissection for cancer.
\end{abstract}

Keywords: Axillary lymph node dissection, chilous fistula, ductus thoracicus

Şilöz kaçak herhangi bir nedenle Duktus torasikusun hasarlanması sonucu gelişen bir komplikasyon olup özellikle baş-boyun ve toraks cerrahisi sonrasında görülen şilöz sızıntının mediasten, plevra ve peritoneal kavitede birikimi nedeniyle ciddi komplikasyonlara neden olabildiği bilinmektedir. Meme cerrahisi sonrası şilöz kaçak gelişimi ise son derece nadir olup aksiller lenf nodu diseksiyonu ile ilgilidir $(1,2)$. 
$\mathrm{Bu}$ yazıda meme kanseri sebebiyle modifiye radikal mastektomi sonrası şilöz kaçak geliştiren 3 hasta ile aksiller lenf nodu diseksiyonu sonrası şilöz kaçaklar irdelenmiş̧ir.

\section{OLGU}

2006-2010 tarihleri arasında meme kanseri sebebiyle modifiye radikal mastektomi yapılan 1294 olgunun 3'ünde şilöz kaçak gelişti. İlk olguda şilöz kaçak intraoperatif olarak fark edildi, vasküler yapı bağlandı ve postoperatif dönemde şilöz kaçak gözlenmedi. İkinci olguda postoperatif 2. günde şilöz görünüm alan aksiller drenaj, postoperatif 12. güne kadar devam etti. Günlük drenaj miktarı ortalama $100 \mathrm{ml}$ civarındaydı. Onikinci günde ameliyathanede eksplore edildi, açık bir lenfatik vasküler yapı görülememekle beraber şüpheli alanlar yeniden bağlanarak ameliyat sonlandırıldı. Postoperatif dönemde şilöz getirisi olmayan olgu taburcu edildi. Üçüncü olguda ise postoperatif 3.günde başlayan şilöz görünümlü drenaj günde ortalama $40-50 \mathrm{ml}$ kadar olup takipte tedricen azalarak sona erdi ve hasta taburcu edildi. Tüm hastalara sol modifiye radikal mastektomi ve sol aksiller diseksiyon yapılmıştı.

\section{TARTIŞMA}

Lenfatik anatomiye baktığımızda; Duktus torasikus birinci lomber vertebra seviyesinde şilöz sisternden ayrılır. Abdomen ve toraksta yükselerek klavikulanın 3-5 $\mathrm{cm}$ üzerinde sol subklavian venin arkasına ulaşır. Buradan öne doğru ani bir açılanma göstererek sol sublavian ve internal juguler venlerin birleşim yerinde sonlanır. Ancak varyasyon göstererek sol internal juguler, sol sublavian, sol brakiosefalik veya eksternal juguler vene drene olabilir. Genellikle venöz açının etrafındaki $1 \mathrm{~cm}$ 'lik alanda sonlanır. Çoğunlukla venöz açının lateral veya posteriorunda sonlanmaktadır; ancak anterolateral sonlanma da tanımlanmıştır. Ayrıca sol internal juguler vene tek bir kanalla sonlanabileceği gibi çoklu kanalla sonlanma da görülebilir $(4,5)$. Dolayısıyla anatomik varyasyonların fazlalığı, açlık durumunda duktusun kollabe olması ve şeffaf görünümü nedeniyle cerrahi sırasında hasarlanmaya son derece açıktır (6). Duktus torasikusun çoğunlukla boynun sol tarafindan drene olması nedeniyle, solda şilöz kaçak görülme ihtimali daha yüksektir; ancak $\% 25$ oranında sağda da görülebilir (3). Burada sunulan olguların da tamamına sol modifiye radikal mastektomi ve sol aksiller disseksiyon yapılmıştı.

Duktus torasikus içinde seyreden şili, lenf sıvısı ve yă̆ sindirimi sonrasında açığa çıkan metabolitlerden oluşu. Duktus torasikus içerisinde şilinin akım hızı; diyet, peristaltizm, öksürük, solunum ve gövde hareketlerine bağlı olarak 2-4 L/gündür $(3,7)$. Dolayısıyla şilöz kaçağın ilk bulgusu oral alım başladıktan sonra yara yerinden drenajın artması olup diyetteki yağ miktarına bağlı olarak drene olan sıvı mavi beyaz ve kremsi görünümdedir. Kaçağın devam etmesi flep nekrozu gibi yara yeri komplikasyonlarına ilaveten sivı, protein ve elektrolit dengesizliği, lenfopeni, malnutrisyon, mediastinit ve şilotoraks gibi ölümcül komplikasyonlara yol açabilir $(3,8)$. Bu sebepten öncelikle tanınması, sonrasında ise uygun tedavi yaklaşımlarının son derece seri bir şekilde gözden geçirilmesi gerekmektedir. Oral alımın kapatılması, orta zincirli yağ asitleri ile total parenteral nutrisyon yapılması, somatostatin analogları, başın elevasyonu ile birlikte yatak istirahati ve sürekli vakum drenaj gibi konservatif yaklaşımlar uygulanabilmekle beraber, Duktus torasikus embolizasyonu, terapötik lenfografi Duktus torasikus ligasyonu, lökorejyonel flep uygulamaları ve lenfatik-venöz anastomozlar gibi cerrahi yöntemler de uygulanabilmektedir $(9,10)$. Tüm bu bilgiler ışığında, nadir de olsa, oluştuğunda ciddi sonuçlara yol açabilecek bir patolojinin, özellikle kanser cerrahisi sebebiyle geniş lenf nodu diseksiyonu yapılan branşlar için bir hatırlatma niteliği taşımasını dileriz. 


\section{KAYNAKLAR}

1. Fitz-Hugh GS, Cowgill R. Chylous fistula. Arch Otolaryngol. 1970; 91(6): 543-7.

2. Donkervoort SC, Roos D, Borgstein PJ. A case of chylous fistula after axillary dissection in breastconserving treatment for breast cancer. Clin Breast Cancer. 2006; 7(2): 171-2.

3. Crumley RL, Smith JD. Postoperative chylous fistula prevention and management. Laryngoscope. 1976; 86(6): 804-13.

4. Davis H. K. A statistical study of the thoracic duct in man. American Journal of Anatomy. 1915; 17: 211-44

5. Kinnaert P. Anatomical variations of the cervical portion of the thoracic duct in man. Journal of Anatomy. 1973; 115: 45-52.

6. van Goor AT, Kröger R, Klomp HM, de Jong MA, van den Brekel MW, Balm AJ. Introduction of lymphangiography and percutaneous embolization of the thoracic duct in a stepwise approach to the management of chylous fistulas. Head Neck. 2007; 29(11): 1017-23.
7. Thawley SE. "How I do it"-head and neck. A targeted problem and its solution. Chylous fistula prevention and management. Laryngoscope. 1980; 90(3): 522-5.

8. Nussenbaum B, Liu JH, Sinard RJ. Systematic management of chyle fistula: the Southwestern experience and review of the literature. Otolaryngol Head Neck Surg. 2000; 122(1): 31-8.

9. Spiro JD, Spiro RH, Strong EW. The management of chyle fistula. Laryngoscope. 1990; 100(7): 7714.

10. Campisi CC, Boccardo F, Piazza C, Campisi C. Evolution of chylous fistula management after neck dissection. Curr Opin Otolaryngol Head Neck Surg. 2013; 21(2): 150-6. 